\title{
ASSESSMENT OF IRON LOADING IN CYPRIOT HOMOZYGOUS BETA-THALASSAEMIC CHILDREN
}

\author{
MAJ C M BATE, MD, FRCP \\ Queen Elizabeth Military Hospital, Woolwich \\ P J BROWN, AIMLS \\ Department of Haematology, University of Liverpool \\ B OELMAN, MSc \\ Ministry of Defence, Stats(G)4, Stanmore \\ M J LEYLAND, MSc, MRCP* \\ Department of Haematology, University of Liverpool
}

SUMMARY: Forty-one patients with homozygous B-thalassaemia and three with haemoglobin $\mathrm{H}$ disease were examined for liver iron concentration, serum ferritin level and the presence of extra medullary haemopoeisis (EMH). Significant correlations were obtained between transfused iron load versus age, liver iron concentration versus transfused iron load and age versus liver iron concentration. Liver iron concentration and age distinguish between severe and intermediate cases. Correlation between serum ferritin and liver iron concentration is highly significant in patients without EMH. Those patients with histological evidence of EMH failed to show this correlation. It is postulated that the presence of EMH is a reffection of ineffective erythropoeisis in the bone marrow of undertransfused patients and that there is thus a large catabolic contribution to the total serum ferritin, explaining the poor correlation between the serum ferritin and liver iron concentration in this group.

\section{Introduction}

Homozygous Beta-Thalassaemia is a common cause of childhood anaemia among the indigenous population of Cyprus, where one in every 118 live born children has the disease ${ }^{1}$. An important complication of the disease is iron overload attendant upon multiple blood transfusions. Increased iron absorption secondary to chronic anaemia and bone marrow hyperplasia may also play a part. The effect of long term chelation therapy on liver iron concentration (LIC), histology and clinical progress in a group of thalassaemic children was recently reported by Barry et $a l^{2}$. These workers compared a group of nine children undergoing regular chelation with a similar number of untreated controls. Iron status was assessed by LIC and transfusion history, The serum ferritin concentration in these patients has also been reported". The children were the offspring of Cypriot immigrants who had settled in Britain, and therefore enjoyed a higher standard of living and medical care than in their country of origin. Iron status and its assessment has not been studied in Cyprus, where dietary and

${ }^{*}$ Now, Department of Haematology, East Birmingham Hospital. 
social conditions, as well as medical management are different. This paper presents the data from a large group of native Cypriot thalassaemics undergoing a low transfusion regime with irregular chelation.

\section{Patients and methods}

Fonty-one patients with homozygous B-thalassaemia and three with haemoglobin $\mathrm{H}$ disease, attending the British Military Hospital (BMH) Dhekelia, were studied. All lived outside the Sovereign Base Area in the surrounding villages, where farming is the main occupation. Their ages ranged from two to 34 years with a mean of nine years. Twenty-three were female and twenty-one male. Three of the females had achieved the menarche and were menstruating regularly. The diagnois of thalassaemia was made by the findings of a typical blood picture in association with a low mean corpuscular volume (MCV) and mean corpuscular haemoglobin $(\mathrm{MCH})$, a raised level of foetal haemoglobin $(\mathrm{HbF})$ and the presence of B-thalassaemia trait in the parents. Three of the patients had a haemoglobin $\mathrm{H}(\mathrm{HbH})$ demonstrated on electrophoresis.

Standard methods ${ }^{4}$ were used for estimating the haemoglobin concentration and examination of the peripheral blood film morphology. Haemoglobin electrophoresis was performed on cellulose acetate at $\mathrm{PH} 6.9^{5}$, followed by elution for haemoglobin quantitation. $\mathrm{HbF}$ was measured by the method of Betke et al ${ }^{b}$. Serum iron and transferrin saturations were measured by the method of Young and Hicks ${ }^{7}$ and the liver iron concentration by the method of Barry and Sherlock $^{8}$. Serum ferritin was measured immunoradiometrically ${ }^{9}$, using an antibody raised to human spleen ferritin, and the normal range established as part of an epidemiological survey of 5,500 patients $^{10}$. The serum bilirubin, alkaline phosphatase, serum glutamic oxalacetic transaminase (SGOT) lactate dehydrogenase (LDH), total serum proteins and serum albumin were all measured by standard laboratory techniques.

Highly accurate transfusion data was available in 25 children (56.8 per cent) who had attended the clinic since they were diagnosed, and all their treatment had been undertaken by one of the authors (C M Bate). The remainder had often been managed at other institutions before presenting to the $\mathrm{BMH}$, and in some cases several years' transfusion history had to be re-constructed, relying on the memories of the patients' parents. This was particularly true of patients T9 and T17. The difficulties this introduced are discussed later. Extramedullary haemopoiesis was recognised by the presence of immature cells of the erythroid or myeloid series, or of megakaryocytes, in the liver biopsy section ${ }^{11}$. A subjective scale was used to estimate its extent. A grading of one corresponded to mild changes, two to moderate changes, and three, extreme changes. All sections were examined without knowledge of the transfusion history. In 12 patients who underwent splenectomy, histological examination of lymph node and splenic tissue was also performed.

\section{Statistical analysis}

The correlations between the parameters under study were examined in two 
ways. In the first it was supposed that a linear relationship existed between any two observations, as described by the equation $\mathrm{Y}=\mathrm{a}+\mathrm{bX}$. This model assumes that $\mathrm{Y}$ increases or decreases in direct proportion with $\mathrm{X}$. In the second, it was held that $\mathrm{Y}$ would increase or decrease with $\mathrm{X}$, but not as a direct proportion. In some instances the rate of increase of $Y$ would be expected to fall as $X$ increased, and in others to increase. This power relationship is described by the equation $Y=a X^{b}$. When $b$ is less than one, the rate of increase of $Y$ decreases as $X$ increases and when $b$ is greater than one, the rate of increase of $Y$ increases and $\mathrm{X}$ increases.

\section{Results}

Table I lists the patients age (in months), the transfused iron load (TIL) in milligrams and the duration of oral iron therapy (IOL) in months. The liver iron concentration is expressed in micrograms per 100 milligrams dry weight of liver. The serum ferritin concentration (FER) was expressed in micrograms per litre and the serum iron concentration (Iron) and total iron binding capacity (TIBC) in micro-moles per litre. The presence or absence of extra-medullary haemopoiesis is also indicated. Those patients whose transfusion history is accurately known are distinguished by an asterisk. Those severely affected children who were chelated or whose disease presented later than usual are indicated. It should be noted that patients one to 67 are suffering from severe homozygous B-thalassaemia and patients four to ST67A, thalassaemia intermedia. The only patient in the series with Lepore thalassaemia was ST67A. Patients 29, 30 and 70 had haemoglobin $\mathrm{H}$ disease. In Table II are shown the patients sex, the age at onset of regular blood transfusions (in months), the age at which splenectomy was performed (in months) and the percentage of circulating haemoglobin $F(F)$ and $\mathrm{A}_{2}\left(\mathrm{~A}_{2}\right)$. Some indication of the presence of liver damage is provided by the SGOT, measured in international units per litre. Table III shows results obtained using both mathematical models for age versus transfused blood load, transfused iron load versus liver iron concentration, ferritin versus transfused iron load (in the absence of EMH), and liver iron concentration versus ferritin corrected for SGOT.

\section{Discussion}

The transfused iron load compared with the age of the patient gives a crude measure of the severity of the disease, and cases of thalassaemia intermedia should form a distinct group compared with severe cases. Figure 1 shows the transfused iron load in milligrams plotted against age in months. Although it can be seen that the intermedias generally have a lower iron load for a given age, the scatter of results is too great to allow for a useful discriminating region. There is a significant correlation using both the linear model $(r=0.574, p<$ $0.001)$ and the power model $(b=0.642, r=0.736, p<0.001)$. It is probable that more accurate transfusion data would enable a useful discriminating zone to be recognised. It can be seen from the figure that the power curve gives a better 
Table I

Summary of iron load data

\begin{tabular}{|c|c|c|c|c|c|c|c|c|c|c|c|}
\hline & & T No & $\begin{array}{c}\text { Age } \\
\text { (months) }\end{array}$ & TIL (mg) & $\begin{array}{c}\text { OIL } \\
\text { (months) }\end{array}$ & $\begin{array}{c}\text { IIC } \\
(\mu \mathrm{g} / 100 \mathrm{mg} d \mathrm{w})\end{array}$ & FER $(\mu \mathrm{g} / 1)$ & $\begin{array}{c}\text { Iron } \\
(\mu \mathrm{mol} / 1)\end{array}$ & $\begin{array}{c}\text { TIBC } \\
\left(\mu_{\mathrm{mol} / \mathrm{l}}\right)\end{array}$ & EMH & NOTE \\
\hline$E$ & $\begin{array}{l}* \\
* \\
* \\
* \\
* \\
* \\
* \\
* \\
* \\
* \\
* \\
* \\
* \\
* \\
* \\
* \\
* \\
* \\
* \\
*\end{array}$ & $\begin{array}{r}1 \\
5 \\
8 \\
9 \\
10 \\
11 \\
12 \\
13 \\
14 \\
16 \\
18 \\
19 \\
20 \\
21 \\
25 \\
26 \\
27 \\
28 \\
31 \\
32 \\
34 \\
36 \\
37 \\
39 \\
41 \\
42 \\
45 \\
49 \\
50 \\
51 \\
60 \\
67\end{array}$ & $\begin{array}{r}129 \\
56 \\
125 \\
165 \\
42 \\
37 \\
40 \\
72 \\
100 \\
74 \\
92 \\
39 \\
207 \\
115 \\
408 \\
25 \\
170 \\
30 \\
35 \\
35 \\
78 \\
25 \\
115 \\
95 \\
141 \\
52 \\
38 \\
24 \\
35 \\
21 \\
145 \\
121\end{array}$ & $\begin{array}{r}5,750 \\
2,250 \\
8,500 \\
10,750 \\
4,385 \\
5,750 \\
3,915 \\
11,750 \\
11,500 \\
14,000 \\
9,500 \\
8,250 \\
13,500 \\
9,750 \\
19,500 \\
3,642 \\
7,000 \\
3,335 \\
3,495 \\
2,995 \\
4,500 \\
4,100 \\
10,750 \\
5,250 \\
11,500 \\
5,750 \\
4,750 \\
4,125 \\
3,500 \\
1,675 \\
5,000 \\
32,500\end{array}$ & $\begin{array}{r}12 \\
0 \\
12 \\
18 \\
0 \\
0 \\
6 \\
? \\
? \\
0 \\
6 \\
0 \\
11 \\
5 \\
? \\
0 \\
? \\
0 \\
0 \\
10 \\
12 \\
? \\
0 \\
30 \\
? \\
? \\
0 \\
1 \\
? \\
3 \\
12 \\
?\end{array}$ & $\begin{array}{l}3,487 \\
1,446 \\
3,363 \\
3,075 \\
1,346 \\
2,209 \\
2,215 \\
2,859 \\
3,426 \\
4,666 \\
2,771 \\
3,359 \\
3,210 \\
1,450 \\
1,764 \\
1,549 \\
3,155 \\
1,840 \\
1,532 \\
1,865 \\
1,269 \\
1,840 \\
4,494 \\
2,602 \\
1,766 \\
2,080 \\
2,395 \\
2,317 \\
2,549 \\
1,009 \\
4,245 \\
4,907\end{array}$ & $\begin{array}{r}1,279 \\
816 \\
2,421 \\
3,352 \\
3,640 \\
4,498 \\
2,646 \\
2,073 \\
2,172 \\
5,027 \\
3,175 \\
2,822 \\
3,131 \\
3,440 \\
2,293 \\
1,786 \\
4,013 \\
2,470 \\
847 \\
2,668 \\
- \\
4,013 \\
2,337 \\
2,051 \\
220 \\
2,800 \\
2,602 \\
664 \\
2,018 \\
1,551 \\
3,704\end{array}$ & $\begin{array}{r}174 \\
80 \\
169 \\
177 \\
95 \\
122 \\
138 \\
172 \\
174 \\
140 \\
131 \\
170 \\
- \\
- \\
104 \\
90 \\
193 \\
148 \\
90 \\
130 \\
95 \\
194 \\
188 \\
196 \\
135 \\
- \\
222 \\
74 \\
36 \\
72 \\
175 \\
192\end{array}$ & $\begin{array}{l}196 \\
229 \\
239 \\
268 \\
262 \\
194 \\
274 \\
194 \\
196 \\
300 \\
- \\
235 \\
- \\
- \\
- \\
240 \\
195 \\
258 \\
255 \\
300 \\
307 \\
266 \\
267 \\
328 \\
215 \\
- \\
284 \\
169 \\
206 \\
217 \\
252 \\
236\end{array}$ & \begin{tabular}{|c}
1 \\
0 \\
1 \\
1 \\
- \\
3 \\
0 \\
3 \\
1 \\
0 \\
1 \\
0 \\
0 \\
$0-1$ \\
1 \\
0 \\
0 \\
1 \\
0 \\
$0-1$ \\
2 \\
0 \\
0 \\
1 \\
2 \\
1 \\
2 \\
3 \\
1 \\
1 \\
1 \\
1
\end{tabular} & $\begin{array}{l}(b) \\
(c) \\
(c) \\
(a) \\
\\
(d) \\
(e) \\
\text { (c) }\end{array}$ \\
\hline $\begin{array}{l}I \\
N \\
T \\
E \\
R \\
M \\
E \\
D \\
I \\
A\end{array}$ & $*$ & $\begin{array}{r}4 \\
6 \\
17 \\
77 \\
100 \\
\text { st67A }\end{array}$ & $\begin{array}{l}139 \\
257 \\
393 \\
254 \\
205 \\
195\end{array}$ & $\begin{array}{r}2,000 \\
1,000 \\
6,000 \\
4,500 \\
8,000 \\
750\end{array}$ & $\begin{array}{r}36 \\
66 \\
? \\
108 \\
? \\
48\end{array}$ & $\begin{array}{r}1,766 \\
3,247 \\
3,065 \\
822 \\
1,676 \\
478\end{array}$ & $\begin{array}{c}3,300 \\
2,073 \\
3,000 \\
915 \\
- \\
-\end{array}$ & $\begin{array}{r}55 \\
74 \\
149 \\
137 \\
- \\
89\end{array}$ & $\begin{array}{c}140 \\
244 \\
202 \\
158 \\
- \\
209\end{array}$ & $\begin{array}{l}1 \\
- \\
0 \\
1 \\
- \\
-\end{array}$ & \\
\hline $\begin{array}{l}\mathrm{H} \\
\mathrm{b} \\
\mathrm{H}\end{array}$ & * & $\begin{array}{l}29 \\
30 \\
70\end{array}$ & $\begin{array}{l}144 \\
103 \\
345\end{array}$ & $\begin{array}{l}1,000 \\
1,000 \\
1,000\end{array}$ & $\begin{array}{r}48 \\
12 \\
?\end{array}$ & $\begin{array}{l}407 \\
430 \\
-\end{array}$ & $\begin{array}{l}384 \\
- \\
410\end{array}$ & $\overline{103}$ & $\begin{array}{c}- \\
236\end{array}$ & $\begin{array}{l}0 \\
0 \\
-\end{array}$ & \\
\hline
\end{tabular}

Note: (a) Late presenter. (b) Intermittent chelation. (c) Continuous chelation. (d) Occasional chelation. (e) Unreliable ferritin assay. 
Table II

Sex, age, at onset of blood transfusion and age at splenectomy

\begin{tabular}{|c|c|c|c|c|c|c|}
\hline T No & Sex & $\begin{array}{l}\text { Age at onset of } \\
\text { regular blood } \\
\text { transfusion (months) }\end{array}$ & $\begin{array}{l}\text { Splenectomy } \\
\text { (months) }\end{array}$ & $\begin{array}{c}\text { Percentage } \\
\mathrm{Hb} F\end{array}$ & $\begin{array}{c}\text { Percentage } \\
\mathrm{Hb} \mathrm{A}_{2}\end{array}$ & SGOT \\
\hline $\begin{array}{r}1 \\
5 \\
8 \\
9 \\
10 \\
11 \\
12 \\
13 \\
14 \\
16 \\
18 \\
19 \\
20 \\
21 \\
25 \\
26 \\
27 \\
28 \\
31 \\
32 \\
34 \\
36 \\
37 \\
39 \\
41 \\
42 \\
45 \\
49 \\
50 \\
51 \\
60 \\
67\end{array}$ & $\begin{array}{l}F \\
F \\
F \\
M \\
M \\
M \\
F \\
M \\
M \\
M \\
M \\
F \\
F \\
M \\
F \\
M \\
M \\
M \\
F \\
M \\
F \\
M \\
F \\
M \\
M \\
F \\
M \\
F \\
F \\
M \\
M \\
M\end{array}$ & $\begin{array}{c}112 \\
53 \\
78 \\
96 \\
9 \\
16 \\
20 \\
12 \\
60 \\
12 \\
12 \\
8 \\
39 \\
65 \\
36 \\
18 \\
132 \\
5 \\
14 \\
17 \\
62 \\
6 \\
15 \\
79 \\
72 \\
41 \\
15 \\
2.5 \\
10 \\
10 \\
130 \\
6\end{array}$ & $\begin{array}{r}54 \\
56 \\
125 \\
60 \\
\text { No } \\
44 \\
\text { No } \\
60 \\
14 \\
\text { No } \\
72 \\
\text { No } \\
30 \\
30 \\
192 \\
\text { No } \\
170 \\
\text { No } \\
\text { No } \\
\text { No } \\
78 \\
\text { No } \\
31 \\
\text { No } \\
130 \\
56 \\
38 \\
24 \\
\text { No } \\
\text { No } \\
129 \\
121\end{array}$ & $\begin{array}{l}31.1 \\
46 \\
5.8 \\
21 \\
68 \\
43 \\
47 \\
13.5 \\
? \\
25 \\
60 \\
19 \\
70 \\
67 \\
25 \\
80 \\
44 \\
62 \\
53 \\
82 \\
55 \\
61 \\
22.5 \\
46 \\
29 \\
63 \\
80 \\
60 \\
53 \\
43 \\
37 \\
12.3\end{array}$ & $\begin{array}{l}4.6 \\
1.0 \\
4.2 \\
2.5 \\
3.8 \\
0.5 \\
2.8 \\
2.9 \\
2.6 \\
0.5 \\
5 \\
2.9 \\
2.0 \\
3 \\
5 \\
2.9 \\
6 \\
2.2 \\
5 \\
1.9 \\
4.7 \\
2.6 \\
1.9 \\
3.5 \\
4.9 \\
2.5 \\
2.5 \\
1.1 \\
2.9 \\
1.4 \\
3.1 \\
3\end{array}$ & $\begin{array}{r}200 \\
68 \\
80 \\
280 \\
60 \\
97 \\
85 \\
75 \\
110 \\
103 \\
92 \\
157 \\
162 \\
125 \\
160 \\
140 \\
220 \\
75 \\
43 \\
145 \\
132 \\
-50 \\
50 \\
82 \\
35 \\
110 \\
65 \\
43 \\
83 \\
92 \\
50 \\
275\end{array}$ \\
\hline $\begin{array}{c}4 \\
6 \\
17 \\
77 \\
100 \\
\text { ST67A }\end{array}$ & $\begin{array}{l}F \\
M \\
M \\
F \\
M \\
F\end{array}$ & $\begin{array}{l}129 \\
228 \\
374 \\
240 \\
180 \\
192\end{array}$ & $\begin{array}{c}38 \\
72 \\
\text { Yes? } \\
252 \\
25 \\
\text { No }\end{array}$ & $\begin{array}{l}45 \\
39 \\
32 \\
- \\
17.3 \\
35\end{array}$ & $\begin{array}{l}4.1 \\
4.8 \\
5 \\
5 \\
3 \\
2\end{array}$ & $\begin{array}{r}233 \\
70 \\
160 \\
83 \\
75 \\
55\end{array}$ \\
\hline $\begin{array}{l}29 \\
30 \\
70\end{array}$ & $\begin{array}{l}F \\
M \\
F\end{array}$ & $\begin{array}{r}133 \\
90 \\
264\end{array}$ & $\begin{array}{l}\text { No } \\
\text { No } \\
\text { No }\end{array}$ & $\begin{array}{l}1.3 \\
1.3 \\
1.9\end{array}$ & $\begin{array}{l}1.1 \\
1.1 \\
1.1\end{array}$ & $\begin{array}{l}33 \\
-\end{array}$ \\
\hline
\end{tabular}


Table III

Summary of statistical analysis

\begin{tabular}{|c|c|c|c|c|c|c|c|c|}
\hline & \multicolumn{4}{|c|}{ Linear model. } & \multicolumn{4}{|c|}{ Pover model } \\
\hline & a & b & $r$ & $\mathrm{p}$ & a & $\mathrm{b}$ & $r$ & $p$ \\
\hline $\begin{array}{l}\text { 1. Age versus TIL } \\
\text { AlI severe cases }\end{array}$ & 3,807 & 45.11 & 0.574 & $<.091 \mathrm{D}$ & 421.8 & 0.642 & 0.736 & $<.001$ \\
\hline $\begin{array}{l}\text { 2. Age versis TIL } \\
\text { AIl severe cases less chelated and late precenters }\end{array}$ & 1,768 & 82.5 & 0.520 & $<.0$ q & 335.4 & 0.707 & 0.670 & $<.001$ \\
\hline $\begin{array}{l}\text { 3. TIL versus IIC } \\
\text { AII severe cases less chelated and late presenters }\end{array}$ & 1,749 & 0.128 & 0.732 & 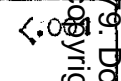 & 23.8 & 0.537 & 0.830 & $<.00 \hbar$ \\
\hline $\begin{array}{l}\text { 4. Age versus IIC } \\
\text { All severe caces less chelated and late presenters }\end{array}$ & 1,267 & 21.66 & 0.779 & $<.0 \% 7$ व & 301.7 & 0.526 & 0.770 & $\angle .001$ \\
\hline $\begin{array}{l}\text { 5. LIC versus FER } \\
\text { AIl severe cases }\end{array}$ & 1,765 & 0.259 & 0.260 & IHS* & 47.6 & 0.508 & 0.287 & NS* \\
\hline $\begin{array}{l}\text { 6. LIC versus FER } \\
\text { All severe cases less } \mathrm{T} 36, \mathrm{EMH}=0\end{array}$ & 156 & 0.859 & 0.772 & $<.01$ 学 & .298 & 1.134 & 0.828 & $<, 01$ \\
\hline $\begin{array}{l}\text { 7. LIC versus FER/SGOT } \\
\text { AII severe cases }\end{array}$ & 22.1 & 0.001 & 0.095 & $\mathrm{NS}^{*}$ & 6.66 & 0.154 & 0.102 & NS* \\
\hline $\begin{array}{l}\text { 8. IIC versus } F E R / S G O T \\
\text { AII severe cases less } 136 \text { with } E M H=0\end{array}$ & 0.025 & 0.009 & 0.787 & 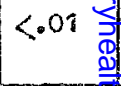 & 0.035 & 0.822 & .743 & $<.05$ \\
\hline $\begin{array}{l}\text { 9. TIL verous FER } \\
\text { AII severe cases }\end{array}$ & 2,110 & 0.057 & 0.287 & NS* 혁 & 575.1 & 0.154 & 0.156 & NS* \\
\hline $\begin{array}{l}\text { 10. TIL versus FER } \\
\text { AII severe cases } 1 \text { ess } T 36 \text { chelated and pate presenter, } \mathrm{EMH}=0\end{array}$ & 508.9 & 0.275 & 0.852 & $<.013$ & 1.858 & 0.809 & 0.832 & $<.05$ \\
\hline $\begin{array}{l}\text { 11. TIL versus FiR/SGOT } \\
\text { AII severe cases }\end{array}$ & 28.2 & -0.0 & -.155 & $\mathrm{NS}^{*} \frac{\mathrm{I}}{\mathrm{O}}$ & 40.47 & -.068 & 0.074 & NS* \\
\hline $\begin{array}{l}\text { 12. TIL versus FR/SGOT } \\
\text { AIl severe cases less } T 36 \text { chelated and late presenters, EMHI=0 }\end{array}$ & 7.74 & 0.03 & 0.839 & $<.01 \mathrm{~g}$ & 0.016 & 0.932 & 0.831 & $<.05$ \\
\hline & & & & $\underbrace{\sigma}_{0}$ & & & & \\
\hline
\end{tabular}




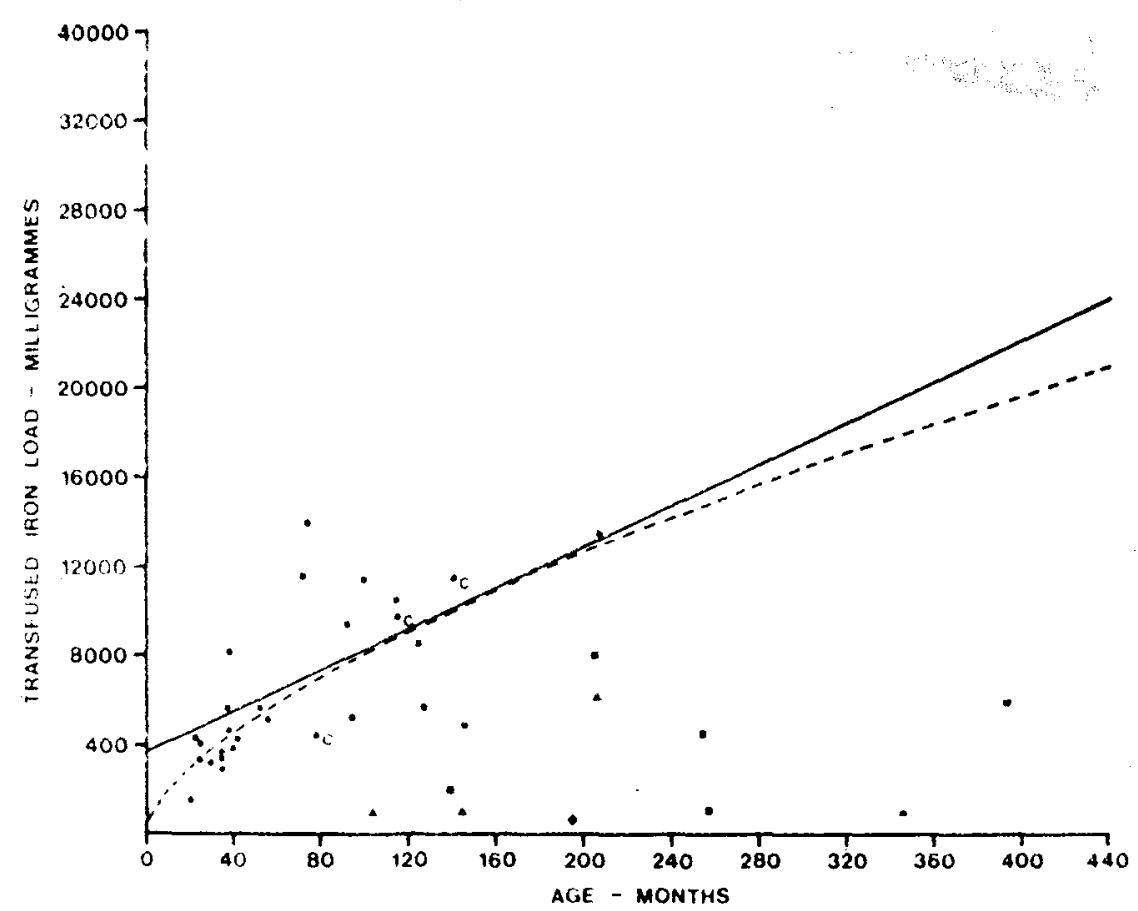

Key

Figs. 1 to 5

- Severe B Thalassaemic

O Severe B Thalassaemic EMH $=0$

- Thalassaemic Intermedia

- Hb H Disease

- Lepore Thalassaemic-Intermedia

Fig. 1. Age versus transfused load.

fit than the linear model, suggesting that the transfusion rate decreases as the patients age increases. This is explained by the clinical observation that a patient's transfusion requirements do lessen after initiation of treatment, possibly because of the reversal of early hypersplenism with reduction in plasma volume. One other factor involved may be that in Cyprus, patients who have survived a longer time, have a less severe form of the disease.

Figure 2 shows the relationship between the liver iron concentration and the transfused blood load. Ignoring chelated cases and the two children who presented late to the clinic, and whose transfusion data is seriously in doubt, it can be seen that the linear model gives a very highly significant correlation $(r=0.830$, $\mathrm{p}<0.001$ ). The linear model has a wide prediction interval, precluding its use as a worthwhile means of directly predicting the liver iron concentration from the transfused load. Again, more reliable transfusion data would probably enable a truly predictive relationship to emerge. The figure shows clearly how chelation has reduced the liver iron concentration in patients T21, 25, 41, 20 and 34 (indicated by the letter $\mathrm{C}$ ). Given the above relationships, a strong correlation would be expected between the age and liver iron concentration. 


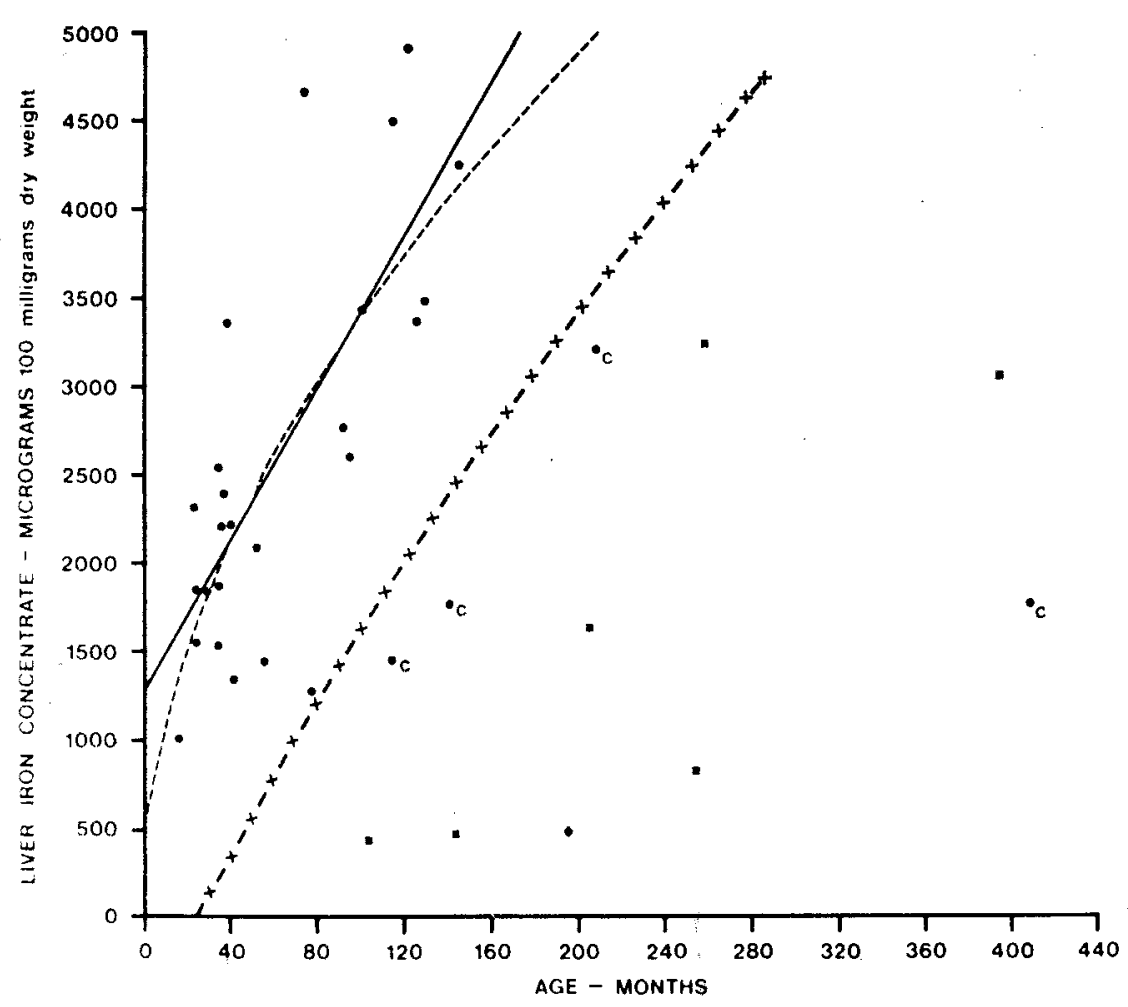

Fig. 2. The relationship between liver iron concentration and transfused iron load.

Figure 3 shows the data plotted. Again, excluding the chelated patients and late attenders with a doubtful transfusion history, both models give a highly significant correlation (Linear: $r=0.779, p<0.001$. Power: $b=0.526, r=0.770$, $\mathbf{p}<0.001$ ). Figure 3 also incorporates a 99 per cent confidence limit on the linear regression, and it can be seen that all unchelated severe cases lie above it, and all the intermedias, haemoglobin $\mathrm{H}$ diseases and chelated cases, lie below it. It would seem that in Cyprus, the liver iron concentration and age, together, can be used to distinguish severe from intermediate cases. Again, chelation can be seen to have a distinct effect on liver iron loading. The concentration of iron in the liver would be expected to reach a maximum value when saturation of the organ was reached. Consequently, an equation showing a reduced rate of increase of liver iron concentration with age might approximate more nearly to the existing biological situation. Using the power model a curve is produced which fits the linear model over most of its length $(b=0.526, r=0.770, p<0.001)$. However, the earlier part of the curve reflects more accurately the higher rate of iron loading occurring during the earlier stages of treatment.

Letsky and her co-workers ${ }^{3}$ showed a high degree of correlation between the serum ferritin concentration and the liver iron concentration $(r=0.75, p<0.001)$ and also between ferritin and transfused iron load $(\mathrm{r}=0.88, \mathrm{p}<0.001)$, and sug- 


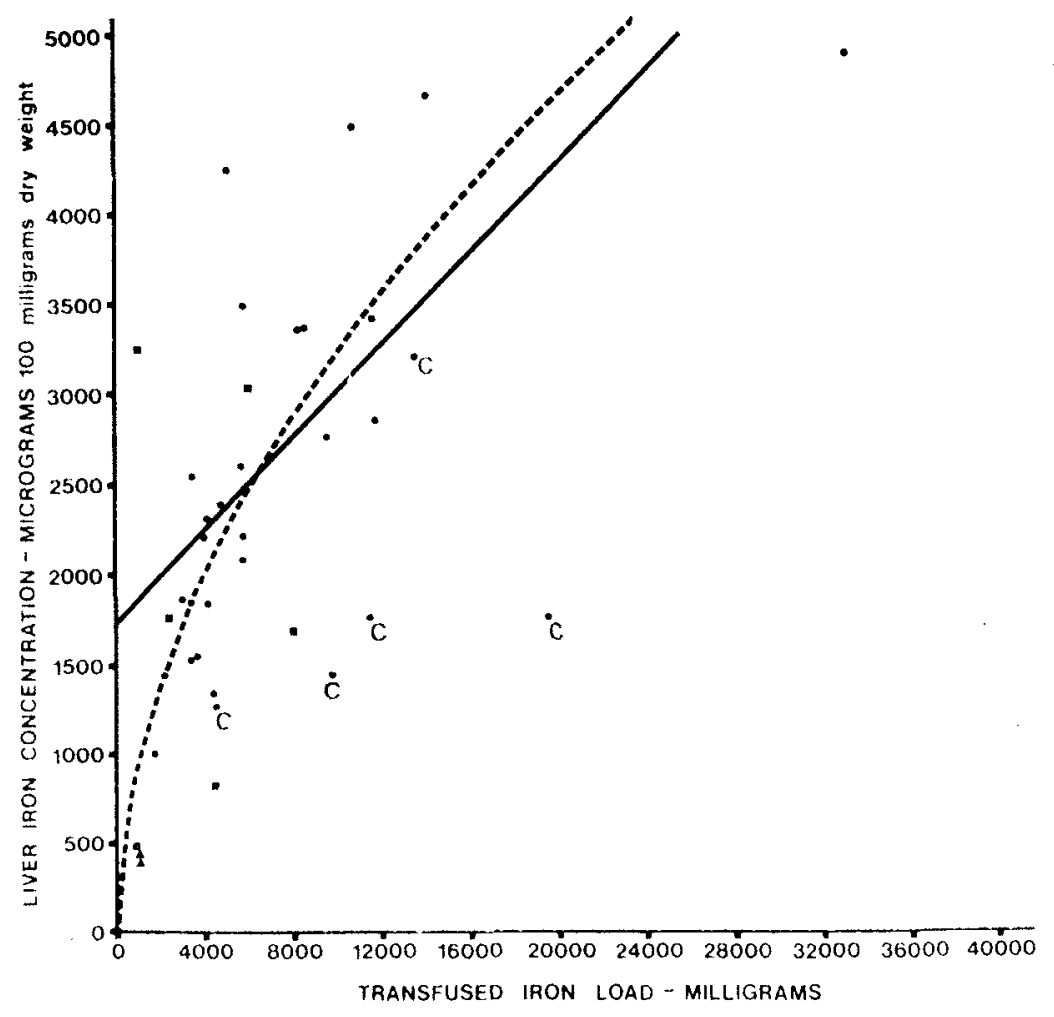

Fig. 3. The relationship between age and liver iron concentration.

gested that measurement of the serum ferritin obviated the need for a liver biopsy when assessing iron loading. However, their patients were managed in the United Kingdom on a hypertransfusion regime designed to suppress marrow hyperplasia, unlike the relatively low transfusion regime offered in Cyprus due to difficulties in obtaining blood.

Considening the data obtained in all the severe cases, the authors found no significant correlation between the serum ferritin concentration and either the liver iron concentration or transfused iron load (Figures 4 and 5). If the 23 patients without extra-medullary haemopoiesis were considered (omitting T36 whose ferritin estimation was unreliable), then a significant linear relationship emerged for both the liver iron concentration $(\mathrm{r}=0.772, \mathrm{p}<0.01)$ and transfused iron load $(\mathrm{r}=0.852, \mathrm{p}<0.01)$. Those patients with histological evidence of EMH failed to show this correlation.

Gabuzda and Pearson ${ }^{12}$ have demonstrated two metabolic forms of ferritin, namely an anabolic form derived from the bone marrow production of red cells and a catabolic form from red cell break down. Under normal circumstances the serum ferritin is believed to be largely due to catabolism, with a small anabolic component. It is postulated that the presence of extra-medullary haemopoiesis 


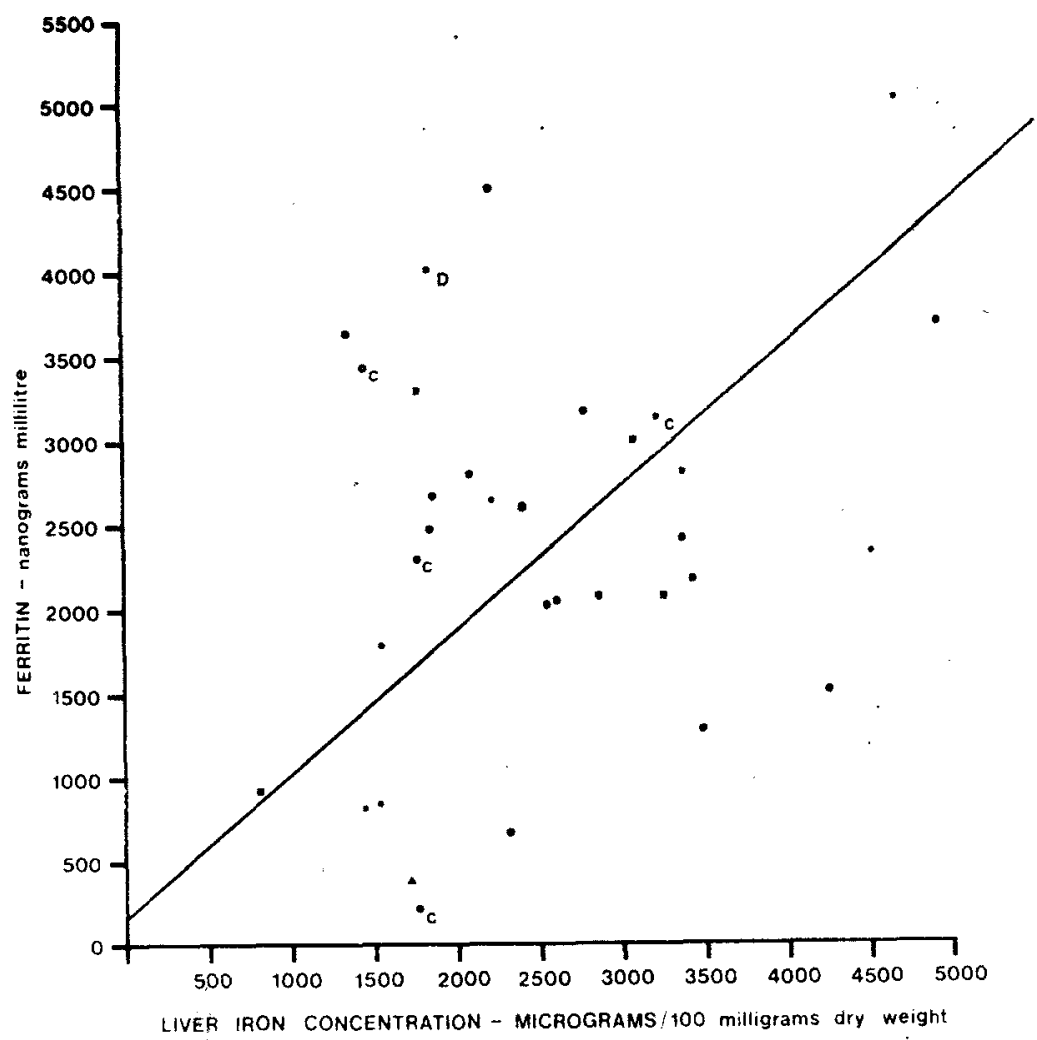

Fig. 4. Serum ferritin versus liver iron concentration.

is a reflection on the intense ineffective erythropoiesis occurring in the bone marrow of under transfused patients. There is thus a large catabolic contribution to the total serum ferritin, explaining the poor correlation between serum ferritin and the other parameters in the whole group.

Prieto et $a^{13}$ and his co-workers, while studying iron overload disorders, found that concomitant liver damage caused an elevation of the serum ferritin and obscured any linear relationship between the liver iron concentration and serum ferritin. However, when the degree of liver damage was allowed for by 'correcting' the liver iron concentration by multiplying it by the serum glutamicoxalecetic transaminase level, a close correlation emerged between this product and the serum ferritin. Applying this correction factor did not alter the correlations already found.

In conclusion, there are several methods of assessing body iron stores, of which the most accurate is the quantitation of mobilizable iron by venesection to the point of iron deficiency ${ }^{14}$. Alternative methods include the urinary iron excretion following a standard dose of chelating agent such as dexferrioxamine ${ }^{15}$, estimation of the liver iron concentration ${ }^{8}$ and estimation of the serum ferritin concentration ${ }^{16}$. In the investigation of the thalassaemic population, venesection is contra-indicated, and in Cyprus, chelating methods are not practical. It is 


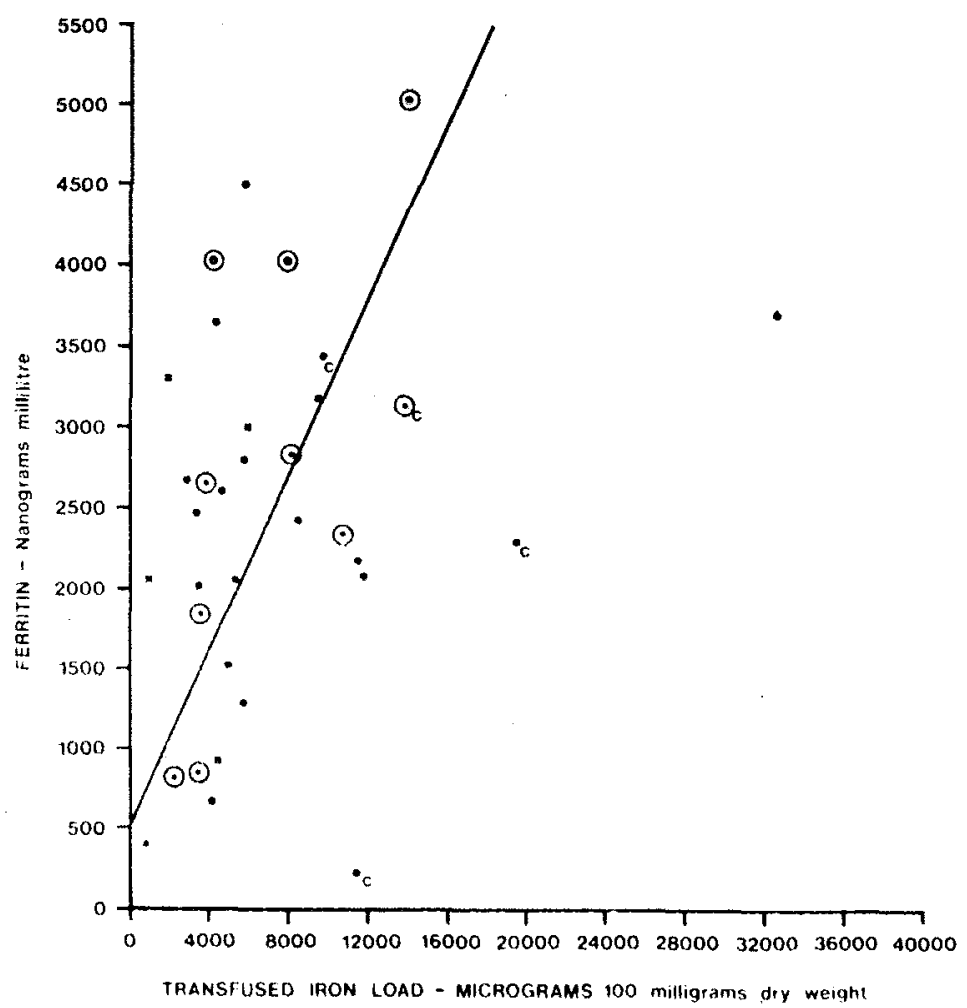

Fig. 5. Serum ferritin versus transfused iron load.

suggested that the measurement of serum ferritin as an index of the body iron stores must be interpreted with caution in patients with bone marrow hyperplasia and extra-medullary haemopoiesis. In a situation such as Cyprus, liver biopsy and estimation of the liver iron concentration would still seem to be the simplest and most accurate method of determining the iron load. It may also be of use in detecting sufferers from thalassaemia intermedia, where elaborate procedures such as chain synthesis are unavailable. It is important to diagnose this group of patients, so that they may be spared unnecessary blood transfusions with consequent iron loading.

\section{REFERENCES-IRONLOADING}

1. BATE, C M (1978) MD Thesis.

2. BARRY, $M$ et al (1974). Long term chelation therapy in thalassaemic major: Effect on liver iron concentration, liver histology and clinical progress. British Medical Journal 2, 16-20.

3. LeTSKy, E A et al (1974). Serum ferritin in children with thalassaemia regularly transfused. Journal of Clinical Pathology 27, 652.

4. Dacie, J and LewIS, S M (1970). Practical Haematology. Churchill, London

5. Graham, J L and Grunbaum, B W (1963). A rapid method of micro-electrophoresis and quantitation of haemoglobins on cellulose acetate. American Journal of Clinical Pathology 39, 567. 
6. BetKe, K, MARTI, H R and SCHLICIT, I (1959). Estimation of small percentages of foetal haemoglobin. Nature 184, 1877.

7. Young, D S and Hicks, J M (1965). Method for the automatic determination of the serum iron. Journal of Clinical Pathology 18, 98.

8. BARRY, M and SHERLock, S (1971). Measurement of liver iron concentration in needle biopsy specimens. Lancet $\mathbf{1}, 100$.

9. AdDISON, G M et al (1972). An immunoradiometric assay for ferritin in the serum of normal subjects and patients with inon deficiency and iron overload. Journal of Clinical Pathology 25, 326-329.

10. Leyland, M J, Harris, H and Brown, P J (1979). Iron status in general practice and its relationship to morbidity. British Journal of Nutrition (In press).

11. Wintrobe, $M$ M et al (1974). Clinical Haematology. Lea \& Febiger, Philadelphia. Pp 57-59.

12. Gabuzda, T G and Pearson, J (1969). Metabolic and molecular heterogeneity of marrow ferritin. Biochemica et Biophysica Acta 194, 50.

13. Prieto, J, Barry, M and Sherlock, S (1975). Serum ferritin in patients with iron overload and with acuter and chronic liver diseases. Gastroenterology 68, 525 .

14. Haskins, D et al (1952). Iron metabolism. Iron stores in mas as measured by phlebotomy. Journal of Clinical Investigation 31, 543.

15. FIELDING, J (1965). Differential ferrioxamine test for measuring chelatable body inon. Journal of Clinical Pathology 18, 88.

16. JACOBS, A et al (1972). Ferritin in the serum of normal subjects and patients with iron deficiency and iron overload. British Medical Journal 4, 206.

\section{Royal College of Surgeons of England}

Lt Col (Professor) M S Owen-Smith, MS, FRCS, has been elected a Hunterian Professor by the Court of the Royal College of Surgeons of England.

\section{Honorary Consultant}

Dr Zoltan H Lett, MD, FFARCSI of the Queen Mary Hospital, Hong Kong, has been appointed Honorary Consultant in Anaesthetics to the Army in Hong Kong, with effect from 9 October 1978. 